\title{
VARIASI BAHASA SUNDA DI DAERAH PESISIR JABAR SELATAN
}

\author{
Asri Soraya Afsari, Teddi Muhtadin \\ Fakultas Ilmu Budaya, Universitas Padjadjaran \\ Surel: asri.s.afsari@unpad.ac.id
}

\begin{abstract}
Abstrak
Setiap bahasa di dunia memiliki variasi. Bentuk variasi bahasa dapat dibedakan berdasarkan letak geografis, sosial, dan temporal. Bahasa Sunda sebagai salah satu bahasa daerah di Indonesia memiliki pula variasi tersebut. Secara geografis, bahasa Sunda yang berada di daerah pegunungan memiliki perbedaan dengan bahasa Sunda di daerah pesisir (pantai). Begitu pun bahasa Sunda yang berada di pesisir Jabar Utara memiliki perbedaan pula dengan bahasa Sunda di pesisir Jabar Selatan. Pangandaran merupakan salah satu wilayah yang ada di lintasan pantai Jabar Selatan. Daerah ini banyak didatangi oleh penduduk yang berasal dari Jawa, seperti Cilacap yang menyebrang ke daerah Jawa Barat. Awalnya para pendatang hanya melakukan perdagangan dan mengadu nasib. Seiring waktu para pendatang tersebut kemudian menikah dengan warga asli dan menetap di Pangandaran. Kehadiran para pendatang tentu membawa banyak pengaruh pada kehidupan masyarakat yang ada di Pangandaran, tidak terkecuali dalam hal bahasa dan budaya. Bahasa Sunda yang digunakan di daerah Pangandaran memiliki karakteristik sendiri. Penelitian ini merupakan penelitian makrolinguistik bidang dialektologi. Penelitian ini bertujuan untuk mendeskripsikan bentuk-bentuk variasi bahasa Sunda yang ada di daerah Pangandaran. Untuk mencapai tujuan tersebut digunakan metode lapangan melalui teknik wawancara informan dan metode survei melalui penyebaran koesioner.
\end{abstract}

Kata kunci: Variasi Bahasa, Dialektologi, Bahasa Sunda, Pesisir Jabar

\section{PENDAHULUAN}

Pengkajian bahasa dapat dilakukan dari berbagai perspektif, misalnya saja semantik mengkaji bahasa dari segi makna baik leksikal maupun gramatikal. Pragmatik mengkaji bahasa dari segi penggunaannya. Begitu pun sosiolinguistik yang mengkaji bahasa dari segi sosial masyarakat bahasa. Dialektologi mengkaji bahasa dari segi geografis. Artinya, bahasa dikaji berdasarkan wilayah penutur bahasa. Dalam sebuah bahasa, faktor-faktor luar bahasa, seperti laut, sungai, gunung dapat pula menentukan perbedaan kata atau makna yang ada pada sebuah bahasa. Perbedaan tersebut melahirkan sebuah variasi dalam sebuah bahasa.

Indonesia adalah negara yang kaya akan bahasa daerah. Dalam bahasa daerah-daerah ini pun terdapat variasi bahasa. Bahasa Sunda sebagai salah satu bahasa daerah yang ada di Nusantara juga memiliki variasi bahasa. Secara geografis, bahasa Sunda yang digunakan di perkotaan, pedesaan, pegunungan, dan pesisir pantai memiliki variasi bahasa yang berbeda. Pangandaran merupakan sebuah wilayah yang terletak di selatan Jawa Barat. Awalnya Pangandaran merupakan sebuah kecamatan di wilayah Kabupaten Ciamis. Kemudian, menjadi nama kabupaten setelah terjadi pemekaran pada 16 November 2012 melalui terbitnya undang-undang nomor 21 tahun 2012. Kabupaten Pangandaran berasal dari sebagian wilayah Kabupaten Ciamis. Kabupaten Pangandaran terdiri atas 10 kecamatan. Wilayah Kabupaten Pangandaran yang termasuk ke dalam wilayah pesisir berjumlah enam kecamatan, yakni Kecamatan Cimerak, Kecamatan Cijulang, Kecamatan Parigi, Kecamatan Sidamulih, Kecamatan Pangandaran, dan Kecamatan Kalipucang (www.pangandarankab.go.id/profilpangandaran/). Penelitian ini akan berfokus pada Kecamatan Kalipucang, dengan mengambil sampel data dari Desa Cibuluh sebab desa ini berbatasan dengan Sebelah Utara Desa Banjar Harjam, Sebelah Selatan dengan Desa Kalipucang, Sebelah Barat Desa Emplak, dan Sebelah Timur dengan Sungai Citanduy sehingga potensi data variasi bahasa Sunda yang akan ditemukan relatif besar. Situasi kebahasaan di Cibuluh banyak dipengaruhi oleh bahasa Jawa. Hal ini disebabkan karena letak Desa Cibuluh berbatasan dengan Jawa tengah, 


\section{KAJIAN TEORI}

Para linguis memberikan batasan mengenai dialek sebagai berikut. Pei (1966: 67) memberikan batasan dialek sebagai cabang atau bentuk tertentu dari bahasa yang digunakan di wilayah geografis tertentu. Richards et al (1987: 80) memberikan batasan bahwa dialek sebagai variasi bahasa yang digunakan di sebagian negeri berupa dialek regional dan oleh penduduk yang memiliki kelas sosial tertentu berupa dialek sosial atau sosiolek, yang memiliki perbedaan dalam hal kata, tata bahasa, dan atau pelafalan yang berbeda dari bahasa yang sama. Adapun Kridalaksana (1993:

42) memberikan batasan dialek sebagai variasi yang beranekaragam menurut penutur, apakah di tempat tertentu sebagai dialek regional, oleh golongan tertentu sebagai dialek sosial, ataukah pada waktu tertentu sebagai dialek temporal. Dari batasan yang dikemukakan oleh para linguis di atas dapat dipahami bahwa dialektologi merupakan kajian tentang variasi bahasa.

Variasi bahasa dipahami sebagai "any body of humans speech patterns whichis sufficiently homogeneous to be analysed by available techniques of synchronic description and which has a sufficiently large repertory of elements and their arragements or processes with board enough semantic scope to function in all normal contexts of communication" (Ferguson \& Gumperz dalam Sobarna 2004). Sehubungan dengan pemahaman ini, Pateda (1990: 52) menyatakan bahwa variasi bahasa memiliki pola-pola bahasa yang sama, polapola tersebut dapat dianalisis secara deskriptif, dan pola-pola tersebut dibatasi oleh makna yang dipergunakan oleh penuturnya untuk berkomunikasi. Nababan (1984: 13) menjelaskan bahwa variasi bahasa mempunyai dua aspek mendasar, yakni bentuk, baik bunyi dan tulisan maupun strukturnya, dan makna, baik leksikal maupun struktural maupun fungsional. Bentuk dan makna bahasa menunjukkan perbedaan-perbedaan kecil-besar antara pengungkapannya yang satu dengan yang lain.

Perihal jenis variasi bahasa, para ahli memberikan pandangan yang berbeda-beda. McDavid (1969) membedakan variasi bahasa berdasarkan pada a. Dimensi regional, b. Dimensi sosial, dan c. Dimensi sosial. Halliday (1970) dalam Sobarna (2004) membagi variasi bahasa berdasarkan pemakaiannya dan pemakainya. Pembagian secara komprehensif dilakukan oleh Pateda (1990). Ia membedakan variasi bahasa atas: (a) tempat; (b) waktu; (c) pemakai, (d) situasi; (e) dialek yang dihubungkan dengan sapaan; (f) status, dan (g) pemakaiannya. Lebih jauh, Pateda (1990:53) menjelaskan bahwa variasi bahasa dapat dilihat dari segi tempat, dalam arti tempat dibatasi oleh air, gunung, atau hutan. Variasi ini menghasilkan apa yang kemudian disebut dengan dialek. Dialek dapat berbeda dalam hal lafal, bentuk kata, atau arti. Dengan demikian, perbedaan tersebut dapat menyangkut: Perbedaan fonologis, morfologis, semantis (sinonim dan homonim), onomasiologis, dan semasiologis.

Metode merupakan cara kerja yang teratur, terpikir baik, dan bersistem untuk memudahkan pelaksanaan suatu kegiatan guna mencapai tujuan yang telah ditentukan (Djajasudarma, 2010: 1). Oleh karena itu, untuk memaksimalkan pencapaian tujuan suatu kegiatan perlu dilakukan pemilihan metode yang tepat. Penelitian ini menggunakan metode lapangan karena peneliti terjun langsung ke masyarakat dengan teknik pengumpulan data utama dengan perekaman. Di samping itu, penelitian ini menggunakan pula kuesioner.

\section{PEMBAHASAN}

Variasi bahasa Sunda yang terdapat di Kecamatan Kalipucang, Pangandaran dapat diklasifikasikan berdasarkan perbedaan dalam hal lafal, bentuk kata, atau arti. Dilihat dari segi kategori kata, variasi bahasa Sunda yang ditemukan berkelas kata nomina, verba, adjektiva, dan adverbia serta berupa partikel. Berikut uraian variasi bahasa Sunda yang terdapat di Kecamatan Kalipucang, Pangandaran.

\section{Perbedaan Fonologis}

Perbedaan fonologis menyangkut perbedaan lafal. Biasanya dalam perbedaan ini penutur tidak menyadari adanya perbedaan tersebut. Pada penelitian ini ditemukan 10 data variasi bahasa Sunda yang termasuk ke dalam perbedaan fonologis, sebagai berikut. 


\begin{tabular}{|l|l|l|l|}
\hline No & $\begin{array}{c}\text { Bahasa Sunda } \\
\text { Pesisir } \\
\text { (Pangandaran) }\end{array}$ & $\begin{array}{c}\text { Bahasa } \\
\text { Sunda } \\
\text { Lulugu }\end{array}$ & $\begin{array}{c}\text { Terjemahan } \\
\text { dalam Bahasa } \\
\text { Indonesia }\end{array}$ \\
\hline 1. & {$[$ cucun] } & turun & turun \\
\hline 2. & {$[$ uhun $]$} & muhun & iya \\
\hline 3. & {$[$ ohong $]$} & bohong & bohong \\
\hline 4. & {$[$ dagongan $]$} & dogongan & dodorongan awi \\
\hline 5. & {$[$ rub $\square \mathrm{s}]$} & robet & $\begin{array}{l}\text { kain yang rusak } \\
\text { pada bagian } \\
\text { pinggir }\end{array}$ \\
\hline 6. & {$[$ [jпk] } & jejek & injak \\
\hline 7. & {$[$ ba $\square]$} & waè & $\begin{array}{l}\text { lagi, kejadian } \\
\text { yang berulang }\end{array}$ \\
\hline 8. & {$[$ miando] } & mindo & menambah nasi \\
\hline 9. & {$[$ amb $\square \mathrm{h}]$} & ameh & $\begin{array}{l}\text { sangkan, supaya } \\
\text { atau agar }\end{array}$ \\
\hline 10. & {$[\mathrm{ND} \mathrm{MHX}]$} & kajeun & biarkan \\
\hline & & & \\
\hline
\end{tabular}

Pada kata cucun terdapat perbedaan fonem konsonan /c/ pada huruf pertama dan ketiga kata turun. Pada kata uhun, ohong, ejek, terdapat perbedaan berupa penghilangan konsonan awal $/ \mathrm{m} /, / \mathrm{b} /$, dan $/ \mathrm{j} /$ pada kata muhun, bohong, dan jejek. Pada kata dagongan terdapat perbedaan fonem vokal /a/ pada huruf ke dua kata dogongan. Pada kata rubet terdapat perbedaan vokal /u/ pada huruf kedua dan konsonan /s/ pada huruf ke lima kata robét. Adapun pada kata miando, ambéh, dan kangjeun terdapat penambahan vokal /a/ pada huruf ketiga kata mindo, penambahan konsonan /b/ pada huruf ketiga kata améh, dan penambahan NRQVRQDQ QDVDO /s/ SDGD KXUXI NH Netiga kata kajeun.

\section{Perbedaan Morfologis}

Perbedaan morfologis menyangkut bentuk kata. Pada penelitian ini ditemukan 6 data variasi bahasa Sunda yang termasuk ke dalam perbedaan morfologis sebagai berikut.

\begin{tabular}{|r|l|l|l|}
\hline No & $\begin{array}{l}\text { Bahasa Sunda } \\
\text { Pesisir } \\
\text { (Pangandaran) }\end{array}$ & $\begin{array}{c}\text { Bahasa } \\
\text { Sunda } \\
\text { Lulugu }\end{array}$ & $\begin{array}{c}\text { Terjemahan } \\
\text { dalam Bahasa } \\
\text { Indonesia }\end{array}$ \\
\hline 1. & {$[$ koh] } & ongkoh & kata penunjuk \\
\hline 2. & {$[$ curugan] } & curug & air terjun \\
\hline 3. & {$[$ kukumbah] } & kumbah & $\begin{array}{l}\text { kegiatan } \\
\text { membersihkan } \\
\text { barang-barang } \\
\text { dengan } \\
\text { menggunakan } \\
\text { air }\end{array}$ \\
\hline 4. & {$[1 \square 1 \square \mathrm{g} \square \mathrm{g}]$} & légég & sombong \\
\hline 5. & {$[$ samarukeun] } & sarukeun & disamakan \\
\hline 6. & {$[$ harah] } & har & $\begin{array}{l}\text { interjeksi untuk } \\
\text { menunjukkan } \\
\text { tidak setuju) }\end{array}$ \\
\hline & & &
\end{tabular}

Pada kata koh terdapat perbedaan morfologis berupa penghilangan suku kata /ong/ pada awal kata ongkoh. Pada kata curugan dan harah terdapat penambahan akhiran -an dan suku kata ah pada kata curug dan har. Pada kata kukumbah dan lélégég terdapat pengulangan pada awal kata kumbah dan légég. Adapun pada kata samarukeun terdapat penambahan suku kata ma pada suku kata kedua kata sarukeun.

\section{Perbedaan Semantis}

Perbedaan semantis dapat timbul karena katakata baru berdasarkan perubahan fonologis dan geseran bentuk. Dalam peristiwa tersebut biasanya terjadi pula geseran makna berupa sinonim dan homonim. Pada penelitian ini variasi bahasa Sunda yang termasuk ke dalam perbedaan semantis berjumlah 12 data sebagai berikut.

\begin{tabular}{|c|c|c|c|}
\hline No & $\begin{array}{c}\text { Bahasa Sunda } \\
\text { Pesisir } \\
\text { (Pangandaran) }\end{array}$ & $\begin{array}{l}\text { Bahasa } \\
\text { Sunda } \\
\text { Lulugu } \\
\end{array}$ & $\begin{array}{c}\text { Terjemahan } \\
\text { dalam Bahasa } \\
\text { Indonesia } \\
\end{array}$ \\
\hline 1. & [kanjat] & meujeuhna & $\begin{array}{l}\text { cukup atau pas } \\
\text { sesuai ukurannya }\end{array}$ \\
\hline 2. & [kunir] & konéng & kunyit \\
\hline 3. & [iatna] & taki-taki & $\begin{array}{l}\text { hati-hati dalam } \\
\text { lakukan hal }\end{array}$ \\
\hline 4. & $\begin{array}{l}\text { [anggah- } \\
\text { ungguh] }\end{array}$ & tatakrama & $\begin{array}{l}\text { robah-robah } \\
\text { awakna, badan } \\
\text { atau bentuk } \\
\text { badannya bisa } \\
\text { berubah }\end{array}$ \\
\hline 5. & [balandongan] & panggung & $\begin{array}{l}\text { panggung } \\
\text { petunjukan pentas } \\
\text { seni }\end{array}$ \\
\hline 6. & [mпndi] & mana & mana \\
\hline 7. & {$[\mathrm{p} \square \mathrm{cl} \square]$} & $\begin{array}{l}\text { éngklé, } \\
\text { sondah }\end{array}$ & $\begin{array}{l}\text { salah satu } \\
\text { permainan } \\
\text { tradisonal anak } \\
\text { sunda yang } \\
\text { permainnanya } \\
\text { dimainkan oleh } \\
\text { empat orang atau } \\
\text { lebih, } \\
\end{array}$ \\
\hline 8. & [pitik] & anak meri & $\begin{array}{l}\text { anak ayam dan } \\
\text { anak meri }\end{array}$ \\
\hline 9. & [camcau] & cincau & $\begin{array}{l}\text { sejenis makanan } \\
\text { atau es yang } \\
\text { terbuat dari daun } \\
\text { cingcau }\end{array}$ \\
\hline 10. & [mubah] & wenang & $\begin{array}{l}\text { boleh (tidak } \\
\text { wajib) }\end{array}$ \\
\hline 11. & [ngaw $\square \mathrm{n} \square$ han] & manggihan & $\begin{array}{l}\text { menemukan, } \\
\text { menemukan } \\
\text { 'barang langka'. }\end{array}$ \\
\hline 12. & [pпcat maot] & nepi maot & $\begin{array}{l}\text { melepaskan } \\
\text { (nyawa) }\end{array}$ \\
\hline
\end{tabular}


Kata kanjat, kunir, iatna, anggah-ungguh, balandongan, mendi, penclé, camcau, mubah, dan pecat termasuk ke dalam sinonim. Kata kunir dan mendi berasal dari bahasa Jawa, kata balandongan diserap dari bahasa Jawa belandongan. Kata mubah dan camcau masing-masing diserap dari bahasa Arab dan bahasa Cina: cincaw. Adapun kata anggah-ungguh sudah jarang digunakan dalam bahasa Sunda lulugu.

Kata pitik dan ngawénéhan termasuk ke dalam homonim. Pitik mengacu pada penamaan untuk 'anak ayam' dan 'anak meri' sedangkan ngawénéhan mengacu pada aktivitas menemukan suatu barang secara umum dan menemukan 'barang langka'.

\section{Perbedaan Onomasiologis}

Perbedaan onomasiologis berkaitan dengan penamaan yang berbeda berdasarkan satu konsep yang diberikan di beberapa tempat yang berbeda. pada penelitian ini ditemukan 2 data variasi bahasa yang termasuk ke dalam perbedaan onomasiologis sebagai berikut.

\begin{tabular}{|l|l|l|l|}
\hline No & $\begin{array}{c}\text { Bahasa Sunda } \\
\text { Pesisir } \\
\text { (Pangandaran) }\end{array}$ & $\begin{array}{l}\text { Bahasa } \\
\text { Sunda } \\
\text { Lulugu }\end{array}$ & $\begin{array}{c}\text { Terjemahan } \\
\text { dalam } \\
\text { Bahasa } \\
\text { Indonesia }\end{array}$ \\
\hline 1 & {$[$ siram $]$} & mandi & mandi \\
\hline 2 & {$[$ tangkar $]$} & $\begin{array}{l}\text { tulang } \\
\text { sapi }\end{array}$ & tulang sapi \\
\hline
\end{tabular}

Konsep aktivitas mandi secara umum di daerah Pangandaran disebut dengan siram sedangkan di daerah Sunda priangan kata siram digunakan pada bentuk halus tingkatan bahasa yang menyatakan aktivitas mandi. Begitu pula pada konsep benda yang mengacu pada bagian rangka tubuh hewan, kata tangkar di daerah Pangadaran digunakan untuk menyatakan tulang sapi sedangkan dalam di daerah Sunda priangan tangkar digunakan untuk menyatakan tulang hewan yang masih muda atau lunak, seperti tulang telinga dan tulang iga pada burung.

\section{SIMPULAN}

Berdasarkan hasil penelitian dapat disimpulkan hal-hal sebagai berikut.

1. Variasi bahasa Sunda di daerah pesisir Jawa Barat (Pangandaran) memiliki perbedaan dengan bahasa Sunda lulugu (Priangan) dalam hal pelafalan, bentuk, dan makna. Perbedaan fonologis berjumlah 10 data, perbedaan morfologis berjumlah 6 data, perbedaaan semantis berjumlah 12 data, dan perbedaan onomasiologis berjumlah 2 data.

2. Dari segi kategori kata, variasi bahasa Sunda yang ditemukan berkelas kata nomina, verba, adjektiva, dan adverbia serta berupa partikel.

3. Berdasarkan perbedaan semantis, variasi bahasa Sunda di pesisir Jawa Barat (Pangandaran) mendapat pengaruh dari bahasa Jawa, Arab, dan Cina.

\section{Daftar Pustaka}

Kridalaksana, Harimurti. 1993 Kamus Linguistik. Jakarta: Gramedia.

McDavid, C. Poster, and C. Biliard (ed)

1974A Manual for Dialect Research in The Southern States. University Alabama.

Nababan. 1984 Sosiolinguistik: Suatu Pengantar. Jakarta: Gramedia.

Pateda, Mansur. 1990 Sosiolinguistik. Bandung: Angkasa.

Pei, Mario. 1966 Glossary of Linguistics Terminology. New York and London: Colombia University Press.

Richards et al. 1987 Longman Dictionary of Applied Linguistics. Longman.

Sobarna, Cece., Tien Wartini, dan Taufik Ampera 2004 Bahasa dan Sastra Daerah di Kabupaten Tangerang. Bandung: Pemkab Tangerang dan Pusat Studi Sunda.

(www.pangandarankab.go.id/profil-pangandaran/ 